\title{
Гибридные перовскиты - прорыв в солнечной энергетике
}

\author{
О.И. Семенова \\ ${ }^{1}$ Институт физики полупроводников им. А.В. Ржанова, Новосибирск, \\ 630090, пр. Лаврентьева, 13 \\ mел:+7 (383) 330-8591, факс:+7 (383) 333-2771, эл.nочта: oisem@isp.nsc.ru
}

DOI 10.34077/RCSP2021-60

Гибридные перовскиты - класс новых синтетических полупроводников с общей формулой $\mathrm{ABX}$, где $\mathrm{A}=\mathrm{CH}_{3} \mathrm{NH}_{3}$ (метил аммоний); $\mathrm{B}=\mathrm{Pb}$ (свинец), $\mathrm{Sn}$ (олово); и $\mathrm{X}=\mathrm{Cl}($ хлор), $\mathrm{Br}($ бром), I(йод). Главным преимуществом гибридных перовскитов является простота получения пленок фотоактивных слоев осаждением из растворов при температурах вблизи комнатной, применение методов струйной печати и специальных чернил, использование стеклянных и гибких пластиковых подложек.

В настоящее время наиболее изученным перовскитом является $\mathrm{CH}_{3} \mathrm{NH}_{3} \mathrm{PbI}_{3}$ - метиламмония трийодид свинца. При использования этого гибридного материала эффективность конверсии солнечной энергии в электрическую для лабораторных однопереходных солнечных элементов (СЭ) возросла с 3,5\% в 2009 году [1] до 25,2\% в 2020 году [2], что подтверждено измерениями NRELНациональной лаборатории возобновляемых источников энергии (США).

По оценкам аналитиков перовскитные солнечные элементы при законченной, разработанной технологии их производства будут примерно в два - три раза дешевле, чем кремниевые, что позволит солнечной энергетике перешагнуть экономически целесообразный порог стоимости. Также большим преимуществом перовскитных тонкопленочных элементов является их высокая удельная мощность на единицу массы активного слоя, не считая подложки. По удельной мощности это самые эффективные в мире солнечные элементы среди всех тонкопленочных.

Настоящим прорывом в последние годы стали исследования и разработки перовскитных тандемных солнечных элементов с кремнием. Рекордным значением эффективности такого СЭ является 29,1\% [2]. В данной технологии перовскитный элемент формируется на поверхности кремниевого солнечного элемента, что позволяет увеличить КПД кремниевых элементов и использовать имеющиеся производственные линии без существенных изменений.

Основные компании, работающие над коммерческим внедрением СЭ из перовскитов:

Oxford PV создана в 2010 профессором Генри Снайт и является одним из крупнейших проектов, работающих над коммерциализацией солнечных элементов на основе перовскита;

Hunt Perovskite Technologies, Даллас, США с 2013 года создает свой эффективный перовскитный солнечный элемент и процесс производства чернил;

китайский Microquanta Semiconductor разработал солнечный модуль большой площади $(200 \times 800$ $\mathrm{cm}^{2}$ ) и запустил пилотную линию мощностью 20 МВт в городе Цюйчжоу, Китай.

Energy Materials, Рочестер, США разработали высокоскоростную печать перовскитных элементов на гибких подложках и получили от Департамента энергетики $\$ 4$ млн финансирования на создание стабильных перовскитных солнечных модулей.

Организация Объединенных Наций ставит задачи по расширению использования солнечной энергетики с нынешней установленной мощности 700 ГВт до 16 ТВт в течение следующих 30 лет.

\section{Лuтература}

[1] A. Kojima et al. // J. Am. Chem. Soc. 2009. V.131, P.6050-6051.

[2] W. National Renewable Energy Laboratory. Best Research-Cell Efficiency Chart. https://www.nrel.gov/pv/cell-efficiency.html 